\title{
User Communities Drivers for Open Innovation
}

\section{Gunnar Prause, Thomas Thurner}

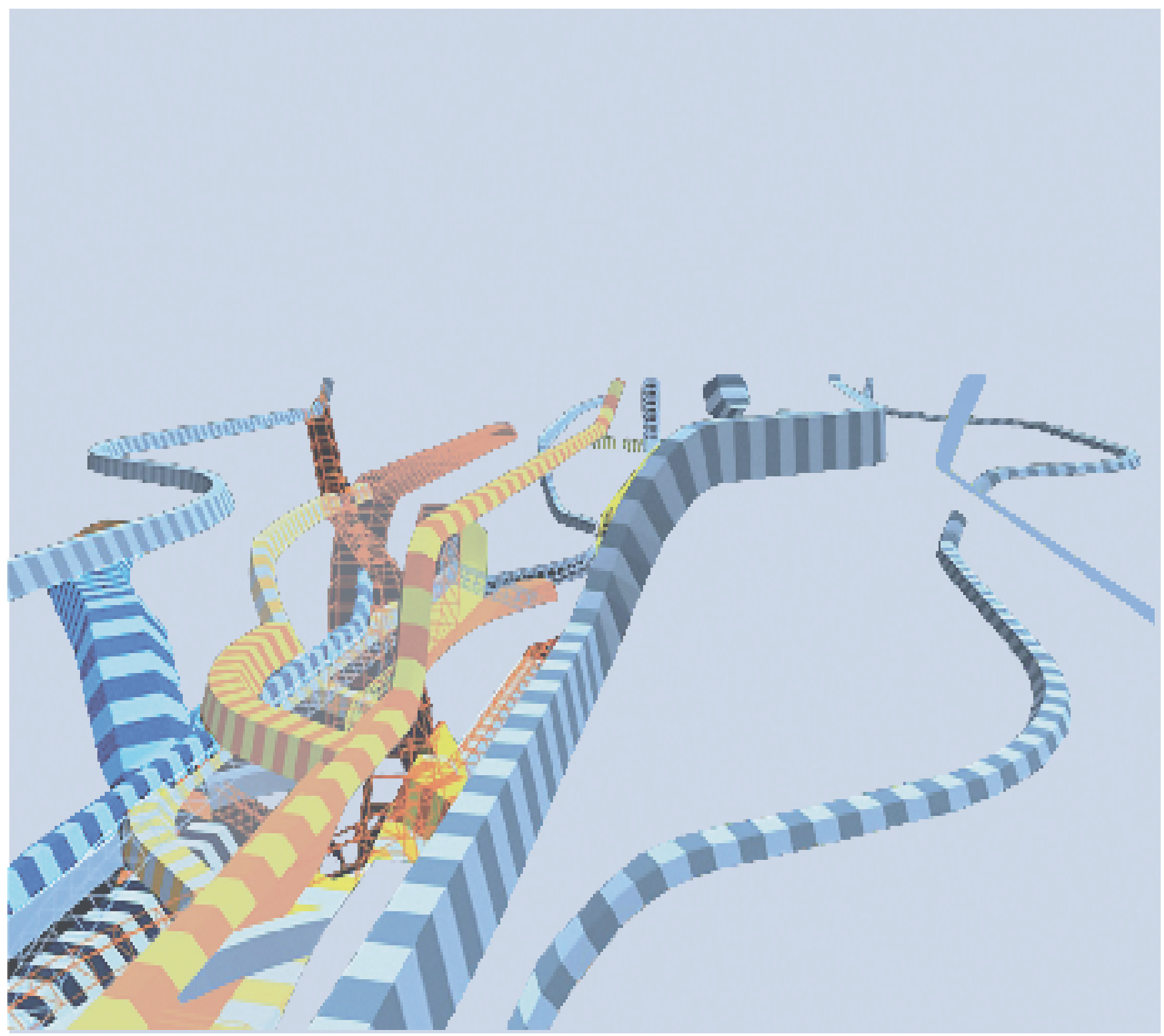

This paper discusses the importance of innovation communities for contemporary innovation management. Based on a detailed literature review and corresponding industry examples, this paper suggests that userdriven innovation through tools like virtual communities, communities of practitioners and living labs will be of increased importance for future innovation processes. Of particular importance for integrating dispersed knowledge, such tools also provide very valuable information sources for strategic planning approaches like foresight.
Gunnar Prause - Professor, School of Economics and Business Administration, Tallinn University of Technology. Address: 3 Akadeemia tee, Tallinn 12618, Estonia. E-mail: gunnar.prause@ttu.ee

Thomas Thurner - Leading Research Fellow, Laboratory for Economics of Innovation, Institute for Statistical Studies and Economics of Knowledge, National Research University - Higher School of Economics, Address: 20 Myasnitskaya str., Moscow 101000 Russian Federation. E-mail: tthurner@hse.ru

Keywords:

open innovation; user innovation; lead users; innovation communities; information and communication technologies; knowledge sharing 


\section{Role of user communities in developing innovation}

Today, innovation is increasingly complex, fast, interactive, and requires the connection of external and internal knowledge bases [Chesbrough, 2003]. Examples for such breakthroughs are plentiful, from the light bulb to double helix DNA mapping [Hargadon, Bechky, 2006]. Consequently, successful innovation is the result of staged and related sub-processes. Firms acquire knowledge from a variety of sources and actors at various spatial scales, combining it with internal knowledge and competences. For this purpose, firms may maintain and use different types of interactions and transfer channels. Localized knowledge and expertise are crucial for competitiveness as innovation processes rely not only on easily accessible knowledge [Stuart, Sorenson, 2003; Porter, 2000] but also on the interplay between local and complementary global knowledge [Gertler, Levitte, 2005; Boschma, Ter Wal, 2007]. Despite the multitude of insights into technology transfer, remarkably little is known about how transfer processes are shaped by the underlying industry and its technical regimes.

The innovation management literature from its beginning started to focus on consumers as a valuable source of knowledge, which could be harvested to inform future innovation. Ultimately, they are the future buyers who could best judge what would lead to commercial success [Jaworski, Kohli, 1993]. Hence, more and more firms engaged in customer involvement for new product ideas which would easily be implemented and highly valued by customers [Kristensson et al., 2004]. Most innovation activities focused on a handful of outstanding customers who - due to their economic weight - would be highly influential for the industry as a whole. If a solution could be developed that convinced these big players, the industry was ripe for the harvest.

A reader who engages with the literature on user-driven innovation will inevitably come across the name of one scholar: Eric von Hippel. He studied the appearances of various movements and aspects of user involvement and user innovation from the mid-1970s onwards. His impressive work focused initially on lead users, and later on innovation communities [von Hippel, 1976, 1986, 1988, 2005; von Hippel, von Krogh, 2003; Lüthje et al., 2005; Shah, 2006].

Originally, user innovators were defined as those individuals who develop new products and services based on their own perceived needs without the assistance and involvement of producers [von Hippel, 1988]. In his recent research, von Hippel introduces some measures to quantify the importance of users in the innovation process and suggests that billions of dollars are spent annually by users to improve products and make them better suited to their needs [von Hippel et al., 2011, 2012]. With respect to scale, von Hippel's surveys found that millions of users collectively spend billions of dollars every year on developing and modifying consumer products. In the UK, 2.9 million people ( $6.1 \%$ of the population) spend a total of $\$ 5.2$ billion annually on this activity. In the US, 16 million people (5.2\% of the US population) collectively spend $\$ 20.2$ billion, and in Japan 4.7 million people (3.7\% of the population) collectively spend $\$ 5.8$ billion to create and modify user products for their own use [von Hippel et al., 2012;
Ogawa, Pongtanalert, 2011]. However, valuable consumerrelated knowledge is widely dispersed, so hearing only one voice might in fact be of little relevance. To fully benefit from this diversity, consumers in large numbers need to be integrated which can be very challenging and expensive. Here, the rapid growth in information technology (web 2) opened new opportunities. Of great interest here are online communities.

The latter in particular has now turned into a very fruitful area of research [Rohracher, 2005]. Innovation from groups of users within and beyond a community has become a topic of great interest recently [Hienerth, 2006; von Hippel, 2005]. These studies of ten focus on user-producer interaction during the various stages of technological development. While earlier works developed well-received tools to allow companies to make use of this valuable resource, this industry focus is also one of the main limitations. This trend toward 'democratizing innovation', as von Hippel calls it, is enhanced substantially by the widespread use of information and communication technology. According to von Hippel, this trend is not only relevant for industries and companies but also for policy makers and various social groups. In 2005, von Hippel compiled this fast-growing cluster of publications in Democratizing Innovation. This is where he introduced the overarching concept of 'innovation community' defined as organized cooperation in the development, testing, and diffusion of user-initiated innovations.

Already earlier, contributions discussed the importance of diversity in innovation communities [Shah, Tripsas, 2004]. Colourful multitudes of people are necessary for creative potential to emerge [Zahay et al., 2011]. They benefit from sharing innovation-related information and early assistance and the provision of complementary skills as these help to improve the functionality and quality of the innovations. The increased interest in the last few years to this topic cannot be explained without a deeper understanding of the advancements in mass communication and the Internet. In addition, the entrepreneurship literature discovered user innovators as an interesting starting point [Hienerth, 2006]. That literature suggests a certain co-evolvement of user innovation and entrepreneurship [von Hippel, 2005]. The emergence phase of user innovation is often spontaneous, contains elements of surprise, and initiated for fun or other non-pecuniary reasons. It can be an individual or collective act. After its birth, innovation diffuses among earlyadopters, who are clustered around the inventors (users) themselves. Lead users develop new functionalities that are practical and applicable in a real life setting [Schreier, Pruegl, 2008]. Their strong technical expertise makes lead users also well suited to contribute original, creative ideas to new functionalities. Lead users can leverage on expertise that reaches considerably beyond specific products and markets and imaginatively apply it to new contexts [Morrison et al., 2004].

Some of the most outstanding companies of today's high technology manufacturing (such as Microsoft, IBM, BMW, and Nokia) are increasingly investing in virtual communities. Other authors even suggest that more than $80 \%$ of firms listed in the S\&P 500 index follow suit. Such wide-reaching changes ultimately lead to major adaption processes within the companies. However, these changes 
did not appear randomly; rather, they were logical developments from open systems and a focus on problem-solving [Chesbrough, 2003; von Hippel, 2005]. Virtual communities and democratic concepts of innovation also enable the SME sector to participate in open innovation approaches. SMEs usually have fewer resources for $R \& D$ relative to larger companies, which results in SMEs patenting less, registering fewer of the other intellectual property rights, and producing fewer technical innovations than larger companies. In other words, we see a positive empirical correlation between innovation activities (including product and process innovations) and company size [Maaß, Führmann, 2012].

Nevertheless, the German SME sector, for example, is responsible for about $20 \%$ of all German patents. By participating in virtual innovation processes, German SMEs can access open and cheap innovations activities by involving key customers and taking a global perspective [Simon, 2007]. SMEs rely on well developed and effective innovation processes due to the high dependency on a small number of products, especially in close cooperation between the company and its customers. With structural mechanisms mostly absent, they generate breeding grounds for nontraditional forms of innovation through knowledge sharing [Perry-Smith, 2006]. Faraj et al emphasize the ways in which online communities can lead to dynamic changes, such as shortening reaction times and discussing a wide variety of ideas [Faraj et al., 2011]. These requirements are a strong argument for producers to adopt these innovations instead of creating them independently. However, more likely than an 'either, -or' decision, the skill lies in choosing between the right options and not to miss great ideas. The digitization of content and virtualization of interactions between firms and their user communities changes the definition of boundaries between the two, and may even modify their respective identities.

The reasons why consumers become members of these online communities and engage so actively are plentiful. First, these communities of ten thrive when users share developments they made largely for their own use. User-touser sharing might not have even been intended at the time of creation. The connection here has often been analysed in the field of open source software [Osterloh, Rota, 2007; Lerner, Tirole, 2005]. Second, people are willing to join and actively participate in online communities - places to exchange ideas with like-minded enthusiasts - because it gives them a positive reputation in their community and provides a way to show their exceptional potential to prospective employers. One's standing in your community is of great interest. Both extrinsic motives (such as peer recognition) and intrinsic motives (including fun, curiosity, or support for others) can play roles. Hosting firms should however balance these motives carefully because a shift might negatively affect customer participation. In fact, studies showed that offering financial rewards might discourage many participants.

Mostly, users feel the need to advance these products to adapt them for alternative use or users (both firms and individuals), who in turn are frequently the first to develop and use prototype versions (e.g. Living Labs). Research studies have discussed how these developments could ultimately become commercially successful new products [Baldwin et al., 2006; Urban, von Hippel, 1988; von Hippel,
$1976,1978,1986,1988]$. The literature in the last two decades has seen growing evidence of successful user-driven innovation from industrial products [Morrison et al., 2004; Riggs, von Hippel, 1994; Urban, von Hippel, 1988; von Hippel, 1976; von Hippel, 1988], consumer products [Baldwin et al., 2006; Franke et al., 2006; Hienerth, 2006; Jeppesen, Frederiksen, 2006; Lüthje, 2004; Lüthje et al., 2005], or new service development [Alam, 2006].

Here, tacit knowledge can be generated and transmitted in virtual communities via commonly used tool kits [Füller, Matzler, 2007]. Von Hippel suggests firms break down innovation tasks into individual smaller tasks which the firm reassembles again [von Hippel, 1994]. To allow firms to harvest this innovative potential, they actively engage in creating the rules of behavior and set the stage for the exchange of ideas [Sawhney, Prandelli, 2000] in assisting other group members to freely share their innovations with others [Füller, Matzler, 2007; Jeppesen, Frederiksen, 2006]. The connection is two-way, as companies also provide members of their communities with their latest products and services for test purposes such as manuals or access to databases about product-related information [Zahay et al., 2011]. One of the major challenges is to decide if the network should stay open or be closed. Niebuhr's results about the relationship between cultural variety and innovation present a strong argument for open networks since her research revealed a significant positive correlation between cultural varieties on innovation power [Niebuhr, 2010]. Open networks have the advantage of being able to access feedback from fringe groups which might not currently be in focus but which might be the upcoming mainstream, making the virtual innovation process independent of social and economic restrictions [Prause, Hunke, 2012]. In the case of closed networks, companies can of course pick the raisins but they also face the need to qualify as innovators [Shah, 2006]. Many diverse skills and previous experiences may help them to better identify potential flaws in product design.

Meanwhile, we notice a change in emphasis from the regional aspect of knowledge and innovation networks towards virtual collaboration concepts in innovation. Virtual collaboration means when ICT - supported networks of companies and institutions co-operate virtually to deploy new innovation potential by integrating third parties like external experts, suppliers, customers or user groups in the innovation process earlier in the process [Kretschmer et al., 2010]. The link of virtual collaboration with virtual communities represents a many-to-many relationship for open innovation processes. Successful examples for such concepts exist in the IT sector. Such examples still have a regional link, such as the 'Living Lab BWe' case which brings together a regional knowledge and innovation network of institutions for electro mobility with current and future user groups. Interestingly, while the lead user approach maintains the boundaries between communities and firms, online communities create more fluent environments, which greatly influence knowledge production. Firms create interfaces like discussion areas for exchanging opinions and ideas and for giving advice on products or services. These interfaces allow companies to become aware of new needs and to integrate potential new uses and new ideas at the design phase. In addition, face-to- 
face meetings with community leaders may happen in the production processes.

Important tools for visualisation and knowledge creation are semantic knowledge maps with pointers to sources, 'tag clouds' that depict the most popular content, and advanced search functionalities to encourage knowledge creation [Antioco et al., 2008]. Computer based tools like Concept Cloud, Concept Web and Correlation Wheel represent powerful methods to gain new knowledge from user feedback based on modern text analytics [Wahl, Prause, 2013]. One of the main criticisms which have been raised recently concerns the efficiency of user-driven innovation. The large number of infrequently participating users brings the risk of redundant information.

\section{Industry examples}

Software engineering has a strong history of user-driven innovation. Of great importance are open source communities. Here, research discussed various concepts like private collective innovation [von Hippel, von Krogh, 2003], commons-based peer production, as well as community-based software development [Shah, 2006]. One of the early examples of consumer-driven innovation is the development of software for music composition [Jeppesen, Frederiksen, 2006]. The architecture of such programs and applications is strongly modular, allowing users to modify, enlarge or forward source code. Central organizational units (such as Linux, Apache or Perl) ensure standardization of the development processes.

Users in the field of video games, however, have been much more active. After Atari's success in the 1970s, the introduction of cheap hardware allowed students to write their own games. Later developments like scripting language and game-oriented interfaces allowed for the development of virtual worlds such as Second Life. Here, opportunities for user-driven innovation - and virtual entrepreneurship were endless. Second Life resembles that of the 'real world' user innovators and entrepreneurs [Shah and Tripsas, 2004; von Hippel, 2005]. This is consistent with the concept of user innovation and entrepreneurship [Shah, Tripsas, 2004; von Hippel, 2005] and the notion of consumers-as-international-entrepreneurs.

There are few examples of innovation in the more expensive and knowledge-intensive hardware sector. One remarkable project in the Dutch college town of Leiden, where a group of residents managed to develop a town wide wireless infrastructure, is illuminating. The original idea was to offer free communication for everybody. Its technical solution was unique. The initiative was so successful that in 2005 it spread to other cities, including cities in Turkey.

User-driven innovation is also becoming more important for the construction industry. Innosite, an initiative of Realdania in collaboration with the Danish Energy Agency, establishes an active innovation environment within Denmark's construction industry to enable exchange of ideas across professions and industries. The platform allows access to players from all aspects of construction, allowing property developers and companies to invite tenders for development assignments, share ideas and provide inspiration for new innovation methods. Companies can set up competitions with the help of Innosite. The users of
Innosite can subsequently submit their proposals and ideas. People with ideas can register as users, put forward proposals for solutions to particular problems, and comment on other users' ideas. The company setting up the competition awards a prize to the best proposal. The main advantage of the platform lies in its potential for cost-savings by collecting and selecting ideas and solutions online rather than in a more traditional way. Moreover, problems and solutions are taken beyond their usual subject and organizationspecific contexts. Open innovation platforms facilitate the involvement of users and experts in the development processes. Indeed, some of the ideas are very interesting: For example, take note of the coloured ice bricks for igloos or summer feelings in the winter city!

Examples of user-driven innovation can be found in large numbers in sports. Here, groups of enthusiasts have developed the equipment for their favourite hobby, whether kite surfing, mountain biking or rodeo kayaking [Hienerth, 2006]. This is particularly true for activities outside the well-funded professional activities (such as handicapped sports). For work on user communities producing innovations in sporting equipment see [Hienerth, 2006; Lüthje et al., 2005].

For example, the snowboard was the invention of winter sport aficionados who had simply become bored with skiing. Skiing was, and remains so, desperate for new ideas to revitalize the market. The Austrian company Edelwiser, which provides personalization of skis, is a good example. After selecting the technical aspects of your equipment, you can choose the colour and design. The service is in great demand: in January 2014, their skis were sold out for the season. The same is true for skateboarding or kite surfing. In the 1990s, only about 5000 individuals participated in white-water paddling. Due to user-driven innovation, the outdoor industry participation study [Outdoor Foundation, 2009 , p. 44] found around 1.2 million people paddling in white-water in 2008 , representing about $15 \%$ of all paddling activities.

The sports-equipment provider Nike integrated the user-generated network niketalk (www. niketalk.com) into their strategic decision-making. The users of the platform discuss existing products of Nike and possible opportunities for improving them. The over 40,000 registered users generate millions of postings. Not only can Nike get very valuable ideas about the user behaviour, it also allows them to identify lead users.

Another area of innovation driven by lead users is medical equipment. The machinery for neuronal surgery, for example, has largely been inspired by doctors who conceived of better solutions for their precise work. Most importantly, though, are user-driven innovations applied in pharmacological substances. For example, doctors discovered that botalium-toxin could reduce muscle spasms. Users later found that it can be used to ease wrinkles. Prior research demonstrated that parents successfully engage in the development and commercialization of baby-related products [Shah, Tripsas, 2004]. Such users have started many international start-ups in knowledge-based industries.

Living Labs have often been established to allow useroriented application in the context of new technologies into innovation processes, starting from the business idea to the launch of the product. The innovation process in this 
case was strengthened by including third party institutions and the public sector. The sustainability of these activities, product success rate, socio-economic acceptance and efficiency of innovations could improve significantly. Benefits of the living lab approach are not restricted to future users and consumers; the SME sector also gains by getting enhanced access to R\&D infrastructure and integration in national and international innovation networks. The living lab for e-mobility in southwestern Germany ('LivinglabBWe') is one example. It comprises a regional collaborative innovation network running 40 projects in e-mobility which includes about 100 companies, institutions and associations on one side, and a virtual and real community of practitioners on the other side. The involvement of users is coordinated by a special Internet platform (http://www.emobilbw.de) to implement low-emission and market-driven mobility with a focus on the strategic fields of market and costs, handling and comfort, and interlinked mobility. The user groups and external experts are integrated into the innovation process in regional seminars and workshops as well as by virtual links via the Internet platform.

Fashion and design are also areas of strong user involvement in innovation processes. The fashion branch above all has to renew its products at least twice a year, and hence trend scouting and the anticipation of future outfits are crucial. Polyvore is the web's largest fashion community site allowing its members to mix and match fashion items from various websites and share newly-created fashion collections ('sets') on the social network. The Polyvore community consists of trendsetters, shoppers and aspiring stylists, who create more than 30,000 sets daily, with over 6 million unique visitors and 140 million page views per month. This makes Polyvore the largest fashion community site in the world. The proposed sets of the Polyvore community can be used by SMEs working in fashion as business models by offering their own products and fashion items from other stores or websites according to the trendy outfits from Polyvore. Another option is to open your own Polyvore profile and offer the Polyvore community a chance to create outfits based on your products i.e. to use the virtual innovation power of the Polyvore community in fashion. Such a business model offering the creative power of virtual communities based on the large sale of standard products has already been realised by larger companies as well as by new start-ups. The largest European mail order trading company 'OTTO Versand' from Hamburg tried to establish its own Fashion Community, based on their own product; so far, it has had only limited success because only around
700 members are linked to the community. The furniture company IKEA has been more successful, with its own community of fans who bring innovative solutions and make proposals for further development of IKEA products. Besides the direct activities of the large retail company IKEA, many new start-ups were created which offer applications and modifications to existing IKEA standard products such as fancy cushions for sofas or add-ons for standard IKEA tables and boards. In this sense, the products and creations offered play the same role as the well-known 'Apps' in the smart phone business.

\section{Conclusions}

Developments in communication technology have enabled new forms of user integration into innovation processes. Virtual communities, communities of practitioners and living labs are examples of how to integrate the dispersed knowledge of users into strategic decision making. In the field of complex and dynamic socioeconomic technologies in particular, the use of virtual communities is a powerful tool to safeguard user oriented and accepted new technologies. New developments show that blended solutions combining living lab concepts with virtual communication, seminars and workshops allow for new levels of open innovation activities. The classical one-to-many approach where one company involves a group of users in the innovation process is changing towards a many-to-many situation where collaborative innovation networks of companies and institutions are trying to involve virtual communities into the innovation process. This development recognises cluster aspects as well as the complexity and interdisciplinarity of new R\&D fields related to sustainability and multimodality. Collaborative innovation approaches also enable the SME sector to be integrated into the complex open innovation concepts which is of specific relevance for economic development.

The knowledge generation of inputs from virtual communities is facilitated by new analysis and data mining tools which make it easy to visualise and detect structures in virtual communication. Computer based tools like Concept Cloud, Concept Web and Correlation Wheel gain new knowledge from user feedback based on modern text analytics.

Increasing man-machine interactions promise much innovation potential if companies succeed in better integrating real life conditions into technical innovations. Early integration of user needs into technical innovations can make people accept and want new products and services more, especially when mobility is complex and dynamic. I $\mathrm{E}$

Alam I. (2006) Removing the fuzziness from the fuzzy front-end of service innovations through customer interactions. Industrial Marketing Management, vol. 35, no 4, pp. 468-480.

Antioco M., Moenaert R.K., Lindgreen A. (2008) Reducing ongoing product design decision-making bias. Journal of Product Innovation Management, vol. 25, pp. 528-545.

Baldwin C., Hienerth C., von Hippel E. (2006) How user innovations become commercial products: A theoretical investigation and case study. Research Policy, vol. 35, pp. 1291-1313.

Boschma R.A., Ter Wal A.L.J. (2007) Knowledge networks and innovative performance in an industrial district: The case of a footwear district in the South of Italy. Industry and Innovation, vol. 14, no 2, pp. 177-199.

Chesbrough H. (2003) Open Innovation: The New Imperative for Creating and Profiting from Technology, Boston: Harvard Business School Press.

Enos J.L. (1962) Petroleum progress and profits: A history of process innovation, Cambridge, MA: MIT Press.

Faraj S., Jarvenpaa S.L., Majchrzak A. (2011) Knowledge collaboration in online communities. Organization Science, vol. 22, pp. $1224-1239$. 
Franke N., von Hippel E., Schreier M. (2006) Finding commercially attractive user innovations: A test of lead-user theory. Journal of Product Innovation Management, vol. 23, pp. 301-315.

Füller J., Matzler K. (2007) Virtual product experience and customer participation - A chance for customer-centred, really new products. Technovation, vol. 27, pp. 378-387.

Gertler M.S., Levitte Y.M. (2005) Local nodes in global networks: The geography of knowledge flows in biotechnology innovation. Industry and Innovation, vol. 12, no 4, pp. 487-507.

Hargadon A.B., Bechky B.A. (2006) When Collections of Creatives Become Creative Collectives: A Field Study of Problem Solving at Work. Organization Science, vol. 17, pp. 484-500.

Hienerth C. (2006) The commercialization of user innovations: The development of the rodeo kayak industry. R\&D Management, vol. 36, no 3, pp. 273-294.

Hyysalo S. (2009) User innovation and everyday practices: Micro-innovation in sports industry development. R\&D Management, vol. 39, no 3, pp. 247-258.

Jaworski B., Kohli A.K. (1993) Market orientation: Antecedents and consequences. Journal of Marketing, vol. 57, pp. 53-70.

Jeppesen L.B., Frederiksen L. (2006) Why do users contribute to firm-hosted user communities? The case of computer-controlled music instruments. Organization Science, vol. 17, no 1, pp. 45-63. DOI 10.1287/orsc.1050.0156.

Kretschmer T., Bolliger K., Koob C. (2010) LIFE 2 - Innovation through Collaboration, Bonn: D-Telekom.

Kristensson P., Gustafsson A., Archer T. (2004) Harnessing the creative potential among users. Journal of Product Innovation Management, vol. 21, pp. 4-14.

Lerner J., Tirole J. (2002) The simple economics of open source. The Journal of Industrial Economics, vol. 50, no 2, pp. $197-234$.

Lüthje C. (2004) Characteristics of innovating users in a consumer goods field: An empirical study of sport-related product consumers. Technovation, vol. 24, no 9, pp. 683-695.

Lüthje C., Herstatt C., von Hippel E. (2005) User-innovators and «local» information: The case of mountain biking. Research Policy, vol. 34, pp. 951-965.

Maaß F., Führmann B. (2012) Innovationstätigkeit im Mittelstand - Messung und Bewertung (IfM-Materialien no 212), Bonn: Institut für Mittelstandsforschung.

Morrison P.D., Roberts J.H., Midgley D.F. (2004) The nature of lead users and measurement of leading edge status. Research Policy, vol. 33, no 2, pp. 351-362. DOI: 10.1016/j.respol.2003.09.007.

Niebuhr A. (2010) Migration and innovation: Does cultural diversity matter for regional RandD activity? Papers in Regional Science, vol. 89 , no 3, pp. 563-585.

Ogawa S., Pongtanalert K. (2011) Visualizing Invisible Innovation Content: Evidence from Global User Innovation Surveys (SSRN Working Paper Series). Available at: http://papers.ssrn.com/sol3/papers.cfm?abstract id=1876186, accessed 14.09.2013.

Osterloh M., Rota S. (2007) Open source software development - Just another case of collective invention? Research Policy, vol. 36, no 2, pp. 157-171.

Outdoor Foundation (2009) 2009 Outdoor Recreation Participation Report, Boulder, CO: The Outdoor Foundation.

Perry-Smith E.J. (2006) Social, yet creative: The role of social relationships in facilitating individual creativity. Academy of Management Journal, vol. 49, pp. 85-110.

Porter C.E., Naveen D. (2008) Cultivating trust and harvesting value in virtual communities. Management Science, vol. 54, no 1, pp. $113-128$.

Porter M. (2000) Location, Competition and Economic Development: Local Networks in a Global Economy. Economic Development Quarterly, vol. 14, no 1, pp. 15-34.

Prause G., Hunke K. (2012) University - Business Interaction in the Context of Demographic Change. European Integration and Baltic Sea Region Studies: University- Business Partnership through the Triple Helix Approach (eds. T. Muravskaya, G. Prause), Berlin: Berliner Wissenschafts-Verlag, pp. 190-203.

Riggs W., von Hippel E. (1994) The Impact of Scientific and Commercial Values on the Sources of Scientific Instrument Innovation. Research Policy, vol. 23, pp. 459-469.

Rohracher H. (ed.) (2005) User involvement in innovation processes. Strategies and limitations from a socio-technical perspective, München, Vienna: Profil Verlag.

Sawhney M., Prandelli E. (2000) Communities of creation: Managing distributed knowledge in turbulent markets. California Management Review, vol. 42, pp. 24-54.

Schreier M., Pruegl R. (2008) Extending lead-user theory: Antecedents and consequences of consumers' lead userness. Journal of Product Innovation Management, vol. 25, pp. 331-346.

Shah S. (2006) Motivation, governance, and the viability of hybrid forms in open source software development. Management Science, vol. 52, no 7, pp. 1000-1014.

Shah S., Tripsas M. (2004) When do user-innovators start firms? Towards a theory of user entrepreneurship (Working Paper 04-0106), Chicago: University of Illinois.

Simon H. (2007) Hidden Champions des 21. Jahrhunderts: Die Erfolgsstrategien der unbekannten Weltmarktführer, Frankfurt/Main: Campus Verlag.

Stuart T., Sorenson O. (2003) The geography of opportunity: Spatial heterogeneity in founding rates and the performance of biotechnology firms. Research Policy, vol. 32, no 2, pp. 229-253.

Urban G., von Hippel E. (1988) Lead user analyses for the development of new industrial products. Management Science, vol. 34, no 5, pp. 569-582.

Von Hippel E. (1976) The dominant role of users in the scientific instrument innovation process. Research Policy, vol. 5, no 3, pp. $212-239$.

Von Hippel E. (1978) Users as innovators. Technology Review, vol. 80, no 3, pp. 3-11.

Von Hippel E. (1986) Lead users: A source of novel product concepts. Management Science, vol. 32, no 7, pp. 791-805.

Von Hippel E. (1988) Lead user analysis for the development of new industrial products. Management Science, vol. 34 , no 5, pp. $569-582$.

Von Hippel E. (1994) Sticky information and the locus of problem solving: Implications for innovation. Management Science, vol. 40, no 4, pp. 429-439.

Von Hippel E. (2005) Democratizing Innovation, Cambridge, MA: MIT Press.

Von Hippel E., de Jong J.P.J., Flowers S. (2012) Comparing business and household sector innovation in consumer products: Findings from a representative study in the United Kingdom. Management Science, vol. 58, no 9, pp. 1669-1681.

Von Hippel E., Ogawa S., de Jong J.P.J. (2011) The age of the consumer-innovator. MIT Sloan Management Review, vol. 53 , no 1, pp. $27-35$.

Von Hippel E., von Krogh G. (2003) Open source software and the «private-collective» innovation model: Issues for organization science. Organization Science, vol. 14, no 2, pp. 209-223.

Wahl M., Prause G. (2013) Toward Understanding Resources, Competencies, and Capabilities: Business Model Generation Approach. Entrepreneurship and Sustainability Issues, vol. 1, no 2, pp. 67-79.

Zahay D., Griffin A., Fredericks E. (2011) Information use in new product development: An initial exploratory empirical investigation in the chemical industry. Journal of Product Innovation Management, vol. 28, pp. 485-502. 